\begin{tabular}{c}
$\begin{array}{c}\text { Brazilian Journal } \\
\text { of Chemical } \\
\text { Engineering }\end{array}$ \\
\hline
\end{tabular}

\title{
TWO-PHASE EXPERIMENTAL HEAT TRANSFER STUDIES ON A WATER-DIESEL SYSTEM IN A SHELL AND TUBE HEAT EXCHANGER
}

\author{
V. Alagesan ${ }^{1 *}$ and S. Sundaram ${ }^{2}$ \\ ${ }^{1}$ School of Chemical and Biotechnology, SASTRA University, Phone: + 919894988976 , \\ Fax: + 91 4362-264120, Thanjavur, Tamil nadu- 613402, India. \\ E-mail: alagesh@chem.sastra.edu \\ ${ }^{2}$ School of Electrical and Electronics Engineering, SASTRA University, \\ Phone: + 91 9894084987, Fax: + 91 4362-264120, Thanjavur, Tamil nadu- 613402, India. \\ E-mail: ss_2410@yahoo.co.in
}

(Submitted: April 26, 2011 ; Revised: November 19, 2011 ; Accepted: December 29, 2011)

\begin{abstract}
Two-phase heat transfer involving two immiscible systems is gaining importance in petrochemical and allied industries. Varying compositions of diesel and water were experimentally studied in a 1:2 shell and tube heat exchanger. The data on pure water and diesel were fitted to an equation of the form. $\mathrm{h}_{1 \varphi}=\mathrm{a} \mathrm{N}_{\mathrm{Re}}^{\mathrm{m}}$. The two-phase multiplier, $\Phi_{\mathrm{L}}$, was related to the Lockhart Martinelli (L-M) parameter, $\chi_{\mathrm{tt}}{ }^{2}$, using the two-phase data and a correlation $\Phi_{\mathrm{L}}=\mathrm{b}+\mathrm{c}\left(\chi_{\mathrm{tt}}{ }^{2}\right)+\mathrm{d} /\left(\chi_{\mathrm{tt}}\right)^{2}$ was established. The two-phase heat transfer coefficient was calculated based on the coefficients ' $a$ ' and ' $\mathrm{m}$ ' for pure diesel and pure water along with $\Phi_{\mathrm{L}}$ and the L-M parameter. The calculated values of the two-phase heat transfer coefficient $h_{2 \varphi}$ based on pure diesel and pure water suggest that diesel is a better reference fluid since the average error is much smaller compared to pure water as reference.

Keywords: Heat transfer coefficient; Shell and tube heat exchanger; Two-phase flow; Lockhart Martinelli parameter; Two-phase multiplier.
\end{abstract}

\section{INTRODUCTION}

In process industries, two-phase flow has gained importance over the years. A better understanding of the rates of momentum and heat transfer in multiphase flow is a must for the optimum design of heat exchangers. Since experimentation in twophase flow is cumbersome, heat transfer coefficient correlations are being developed using pure fluid thermo-physical properties, dimensionless numbers such as the Reynolds number and Nusselt number.

Considerable research is being pursued in twophase flow particularly in the area of fluid dynamics.
Lockhart et al. (1949) carried out the first detailed study in gas-liquid two-phase flow and proposed a correlation for isothermal two-component flow in pipes. Thorbjon et al. (1972) presented a theoretical method for predicting the hold up in stratified and wavy two-phase flow. This theoretical solution agrees well with the generalized empirical solution developed by Lockhart and Martinelli (L-M) for all regimes. Subsequently, many researchers have used this approach for hydrodynamic and pressure drop studies in gas-liquid two-phase flow in various geometries such as vertical tube (Spedding et al., 1980; Vijayarangan et al., 2007; Xiuzhong et al., 2005), horizontal tube (Rani Hemamalini et al.,

*To whom correspondence should be addressed 
2005;), vertical and horizontal tube (Benbelk A. Shannak., 2008), across staggered rod bundles (Dowlati et al., 1992), helicoidal pipes (Awwad et al., 2000), etc. The heat transfer for gas-liquid flow in a plate type heat exchanger has also been investigated (Vlasogiannis et al., 2002). Ramachandran et al. (2006) conducted two-phase experiments in a compact heat exchanger and developed heat transfer correlations for two-phase heat transfer involving liquid-liquid systems. Ramachandran et al. (2008) developed a model for predicting the two-phase heat transfer coefficient of liquid-liquid systems using single phase data.

In this work, we propose a model formulation analogous to the L-M parameter model for heat transfer involving a liquid-liquid mixture. However, the study of heat transfer involving two immiscible liquids in a shell and tube heat exchanger has not been extensively studied. Experiments were carried out in a shell and tube heat exchanger with hot water as the heating fluid (service fluid) and two-phase mixtures of water-diesel in different ratios as the heated fluid (process fluid) on the shell side. The heat transfer coefficients on the shell side were correlated with Reynolds numbers and the relations between the Lockhart-Martinelli parameter, the quality and the two-phase multiplier were developed based on the experimental data. The work is confined to laminar flow in the present study.

\section{EXPERIMENTAL SECTION}

A schematic diagram of the 1-2 pass shell and tube heat exchanger experimental setup is shown in Figure 1, which gives in detail the size and specifications of all the units involved. Triangular pitch was used for the arrangement of tubes. Heating fluid and process fluid were pumped through the tube and shell side of the heat exchanger, respectively, using $0.25 \mathrm{HP}$ pumps. Water was heated using a $2 \mathrm{~kW}$ heater and the temperature of the hot fluid was maintained constant at $70^{\circ} \mathrm{C}$ in the tank using suitable thermostats with an accuracy of $\pm 0.5^{\circ} \mathrm{C}$. Pumping continued through both the channels until a steady state was obtained with respect to the inlet and outlet temperatures of both the fluids. The flow rate was measured using Gallenkamp rotameters with an accuracy of \pm 0.1 LPM. The hot water flow rate was constantly maintained by rotameter R1 and circulated through the tube side, while the shell side test fluid mixture was metered through rotameter R2. The rotameters were calibrated before use. The flow rates of the two streams were adjusted using hand operated valves (2) and (4). The temperatures were recorded in the exit and inlet using RTD with an accuracy of $\pm 0.1^{\circ} \mathrm{C}$. Six compositions ( $0 \%$ to $100 \%$ diesel) of the waterdiesel system were used in the study. The two-phase system was kept in suspension using an agitator.

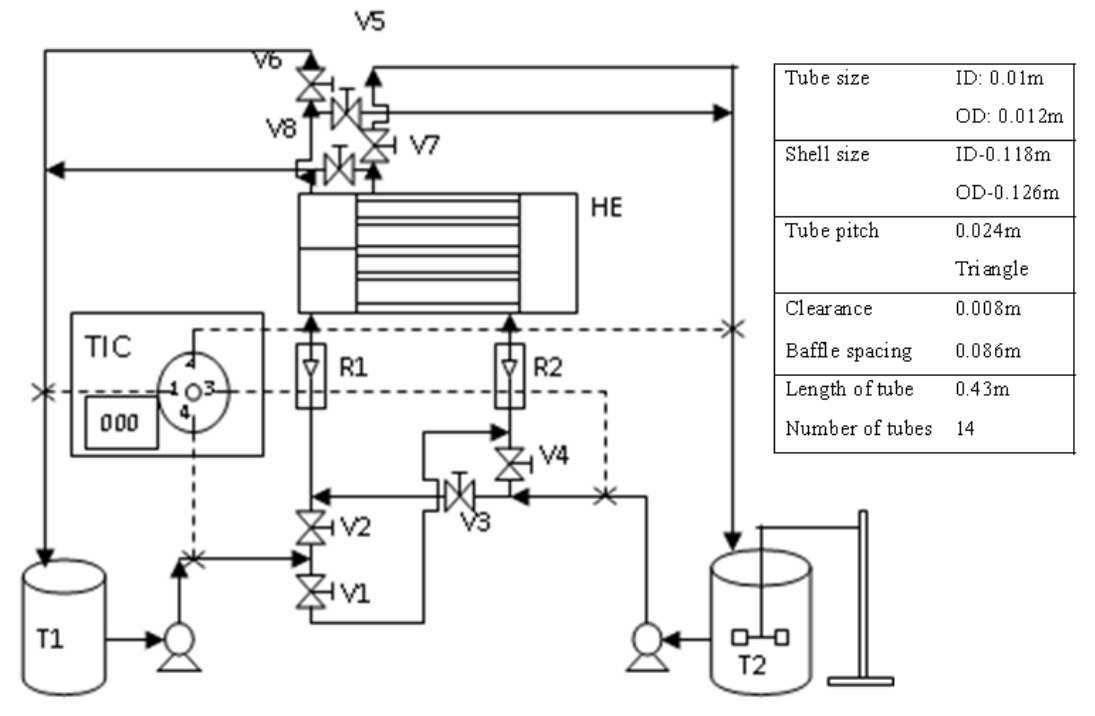

Figure 1: A systematic diagram of the experimental setup. [solid lines - Flow; dotted lines - temperature sensor; 1, 4-RTD's for inlet \& outlet hot fluid; 2, 3 RTD's for inlet \& outlet cold fluid; R1, R2 - rotameters; V1, V2, V3, V4, V5, V6, V7, V8 - manual valves; HE - heat exchanger; TIC - temperature indicator controller; T1 - hot fluid storage tank; T2 - cold fluid storage tank]. 


\section{CALCULATION METHODOLOGY}

\section{Tube Side}

On the tube side, the heating fluid (hot water) circulated at a constant rate. The tube side Reynolds number, Nusselt number, heat transfer coefficient and heat transfer rates were calculated using Equation (1) to (4).

$\mathrm{N}_{\mathrm{Re}}=\frac{\mathrm{vD}_{\mathrm{i}} \rho}{\mu}$

$\mathrm{N}_{\mathrm{Nu}}=1.86\left\{\frac{\mathrm{N}_{\mathrm{Re}} \mathrm{N}_{\operatorname{Pr}}}{\mathrm{L} / \mathrm{D}_{\mathrm{i}}}\right\}^{0.333}$

$\mathrm{h}_{1 \mathrm{t \phi}}=\left(\frac{\mathrm{N}_{\mathrm{Nu}} \mathrm{k}}{\mathrm{D}_{\mathrm{i}}}\right)$

$\mathrm{Q}=\mathrm{m}_{\mathrm{h}} \mathrm{C}_{\mathrm{ph}}\left(\mathrm{T}_{\mathrm{h} 2}-\mathrm{T}_{\mathrm{h} 1}\right)$

The properties $\mu, \rho, \mathrm{k}$ were calculated based on the average of the inlet and outlet temperatures.

\section{Shell Side}

Various compositions of diesel and water were circulated at different flow rates. The heat transfer coefficients for the single phases were related to the Reynolds number using Equation (5) and the constants a and $\mathrm{m}$ established by regression analysis.

$\mathrm{h}_{1 \phi}=\mathrm{aN}_{\operatorname{Re}}^{\mathrm{m}}$

The quality (X) is defined by Equation (6),

$$
X=\frac{1}{\left[1+\frac{\left(\rho_{w} V_{w}\right)}{\left(\rho_{f} V_{f}\right)}\right]}
$$

The Reynolds number is calculated based on Equation (7) to (12):

$$
\begin{aligned}
& \rho_{\mathrm{m}}=\rho_{\mathrm{f}} \mathrm{X}+\rho_{\mathrm{w}}(1-\mathrm{X}) \\
& \mu_{\mathrm{m}}=\mu_{\mathrm{f}} \mathrm{X}+\mu_{\mathrm{w}}(1-\mathrm{X}) \\
& \mathrm{A}_{\mathrm{S}}=\left(\frac{\mathrm{P}_{\mathrm{t}}-\mathrm{D}_{\mathrm{o}}}{\mathrm{P}_{\mathrm{t}}}\right) \mathrm{D}_{\mathrm{S}} \mathrm{B}_{\mathrm{S}}
\end{aligned}
$$

$\mathrm{G}_{\mathrm{S}}=\left(\frac{\mathrm{V}_{\mathrm{m}} \rho_{\mathrm{m}}}{\mathrm{A}_{\mathrm{S}}}\right)$

$\mathrm{D}_{\mathrm{e}}=\frac{1.1}{\mathrm{D}_{\mathrm{o}}\left(\mathrm{P}_{\mathrm{t}}{ }^{2}-0.91 \mathrm{D}_{\mathrm{o}}{ }^{2}\right)}$

$\mathrm{N}_{\mathrm{Re}}=\left(\frac{\mathrm{G}_{\mathrm{S}} \mathrm{D}_{\mathrm{e}}}{\mu_{\mathrm{m}}}\right)$

The correction factor $\left(\mathrm{F}_{t}\right)$ is a function of the shell and tube fluid temperatures and was correlated as a function of two dimensionless temperature ratios (Sinnott, 2000):

$\mathrm{R}=\frac{\left(\mathrm{T}_{\mathrm{c} 1}-\mathrm{T}_{\mathrm{c} 2}\right)}{\left(\mathrm{T}_{\mathrm{h} 1}-\mathrm{T}_{\mathrm{h} 2}\right)}, \quad \mathrm{S}=\frac{\left(\mathrm{T}_{\mathrm{h} 2}-\mathrm{T}_{\mathrm{h} 1}\right)}{\left(\mathrm{T}_{\mathrm{c} 1}-\mathrm{T}_{\mathrm{h} 1}\right)}$

$\mathrm{R}$ is equal to the shell side fluid flow rate times the fluid mean specific heat divided by the tube side fluid flow rate times the tube side fluid specific heat.

$\mathrm{S}$ is a measure of the temperature efficiency of the exchanger.

The true temperature difference is expressed as:

$$
\Delta \mathrm{T}_{\mathrm{m}}=\mathrm{F}_{\mathrm{t}} \Delta \mathrm{T}_{\mathrm{lm}}
$$

The overall heat transfer coefficient $(\mathrm{U})$ and process side heat transfer coefficient $\left(\mathrm{h}_{2 \varphi}\right)$ are determined using Equation (15) and (16):

$$
\mathrm{U}=\frac{\mathrm{Q}}{\mathrm{A}_{\mathrm{h}} \Delta \mathrm{T}_{\mathrm{m}}}
$$

$$
\mathrm{h}_{2 \phi}=\frac{1}{\left\{\left(\frac{1}{\mathrm{U}}\right)-\left(\frac{\mathrm{D}_{\mathrm{o}} \ln \left(\frac{\mathrm{D}_{\mathrm{o}}}{\mathrm{D}_{\mathrm{i}}}\right)}{2 \mathrm{k}_{\mathrm{w}}}\right)-\left(\frac{\mathrm{D}_{\mathrm{o}}}{\mathrm{D}_{\mathrm{i}} \mathrm{h}_{1 \mathrm{t} \phi}}\right)\right\}}
$$

The single phase heat transfer coefficient was related to the Lockhart-Martinelli parameter $\left(\chi_{t t}^{2}\right)$ using the slope ' $\mathrm{m}$ ' of Equation (5).

$$
\chi_{\mathrm{tt}}^{2}=\left(\frac{1-\mathrm{X}}{\mathrm{X}}\right)^{2-\mathrm{m}}\left(\frac{\rho_{\mathrm{f}}}{\rho_{\mathrm{f}}}\right)\left(\frac{\mu_{\mathrm{w}}}{\mu_{\mathrm{f}}}\right)^{\mathrm{m}}
$$

The ratio of the two-phase heat transfer coefficient to the single phase heat transfer coefficient is expressed as the two-phase multiplier $\left(\Phi_{\mathrm{L}}\right)$ : 


$$
\Phi_{\mathrm{L}}=\frac{\mathrm{h}_{2 \phi}}{\mathrm{h}_{1 \phi}}
$$

Equation (19) relates the two-phase multiplier to the L-M parameter:

$\Phi_{\mathrm{L}}=\mathrm{b}+\mathrm{c} \chi_{\mathrm{tt}}^{2}+\frac{\mathrm{d}}{\chi_{\mathrm{tt}}^{2}}$

The error is defined by Equation (20) as,

Error $=\left[\frac{\mathrm{h}_{2 \phi}(\exp )-\mathrm{h}_{2 \phi}(\mathrm{cal})}{\mathrm{h}_{2 \phi}(\exp )}\right] 100$

\section{RESULTS AND DISCUSSION}

Figure 2 shows the variation of the single and the two-phase heat transfer coefficients with Reynolds number for the shell side process fluid. It is seen that the two-phase data fall within the boundaries of the pure water and pure diesel data. In addition, the increase in agitation enhances the uniformity of the two-phase mixture, thus preventing stratification of the phases. Hence, the overall physical properties of the mixture remain uniform throughout the flow channel. The uniformity of the two-phase mixture, coupled with increased convective currents driven by higher flow velocities, results in higher heat transfer coefficients.

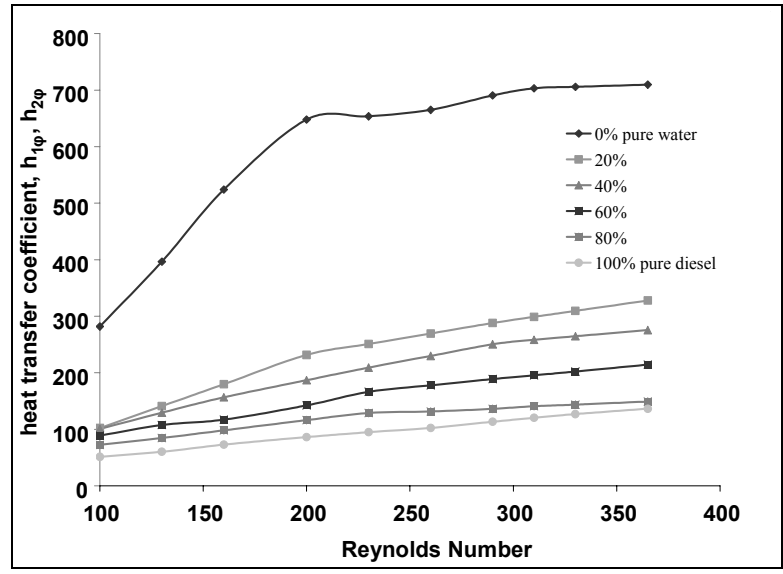

Figure 2: Variation of the heat transfer coefficient with Reynolds number for different diesel -water compositions.
Figures 3 and 4 show the single phase heat transfer coefficient $\left(\mathrm{h}_{1 \varphi}\right)$ and Reynolds number relationship for pure diesel and pure water, respectively. The data for pure fluid (diesel or water) was fitted to Equation (5) by regression analysis and the resultant constants a and $\mathrm{m}$ for diesel and water are given in Table 1. Initially the L-M parameter correlation was used for predicting the pressure drop of gas-liquid two-phase systems and then the heat transfer coefficients for liquid-liquid two-phase flow were related to the L-M parameter (Ramachandran et al., 2006, 2008) in Equation (17), where ' $m$ ' represents the power to which the Reynolds number is raised to determine the single phase heat transfer coefficient. The inlet and outlet temperatures of the shell side and tube side fluid are shown in Table 2 for different compositions. We maintained the inlet temperatures constant and measured the outlet temperatures once the heat exchanger attained the steady-state condition. The two-phase multiplier $\Phi_{\mathrm{L}}$ (Equation (18)) and the L-M parameter (Equation (17)) are shown in Figures 5 and 6 for $80 \%$ composition of the diesel-water system based on pure diesel and pure water, respectively, and are related by the heat capacity (Equation (19)). The variation of the two-phase multiplier $\left(\Phi_{\mathrm{L}}\right)$ with the L-M parameter $\left(\chi_{\mathrm{tt}}{ }^{2}\right)$ shows an increasing concave trend, while the $\mathrm{h}_{1 \varphi}$ of pure diesel is less than the heat transfer coefficient of the two-phase mixture. Because $h_{1 \varphi}$ based on pure water is higher than $h_{2 \varphi}$, the trend between $\Phi_{\mathrm{L}}$ and $\chi_{\mathrm{tt}}{ }^{2}$ is upwardly concave. The constants b, c and d of the heat capacity correlation (Equation (19)) are given in Table 3 based on pure diesel and pure water as the reference fluid. The relationship of quality to the L-M parameter and the two-phase multiplier are shown in Figures 7 and 8. An increasing L-M parameter $\left(\chi_{\mathrm{tt}}{ }^{2}\right)$ for the diesel-water system denotes a decrease in quality $(\mathrm{X})$ and implies an increase in the two-phase multiplier $\left(\Phi_{\mathrm{L}}\right)$. As the proportion of the second phase increases, with a consequent decrease in the proportion of water, the viscosity of the mixture increases and the thermal conductivity, density and specific heat decrease. This brings down the heat transfer coefficient and hence the two phase multiplier decreases with quality. Tables 4 and 5 compare the two-phase heat transfer coefficients calculated based on pure diesel and pure water as the reference fluid. Table 6 summarizes the average absolute deviation of the two-phase heat transfer coefficients calculated using water and diesel as reference liquids for the data in Tables 4 and 5. 


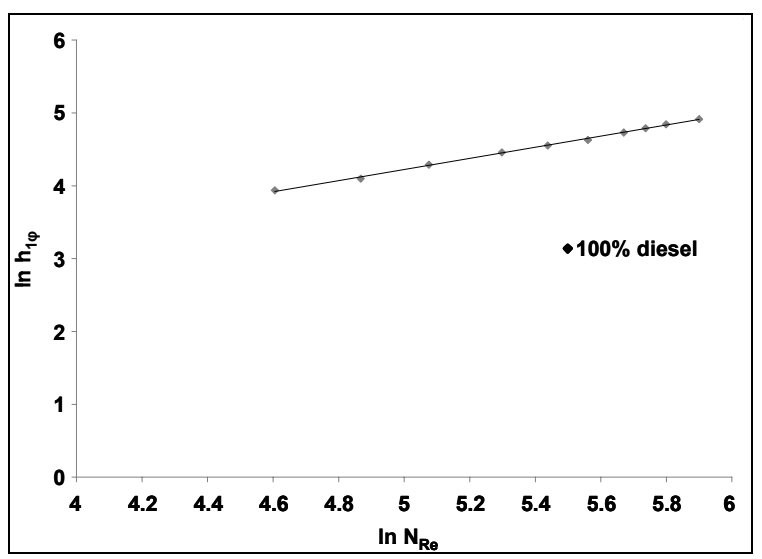

Figure 3: Plot between $\ln \mathrm{N}_{\mathrm{Re}}$ and $\ln \mathrm{h}_{1 \varphi}$ (heat transfer coefficient of pure diesel).

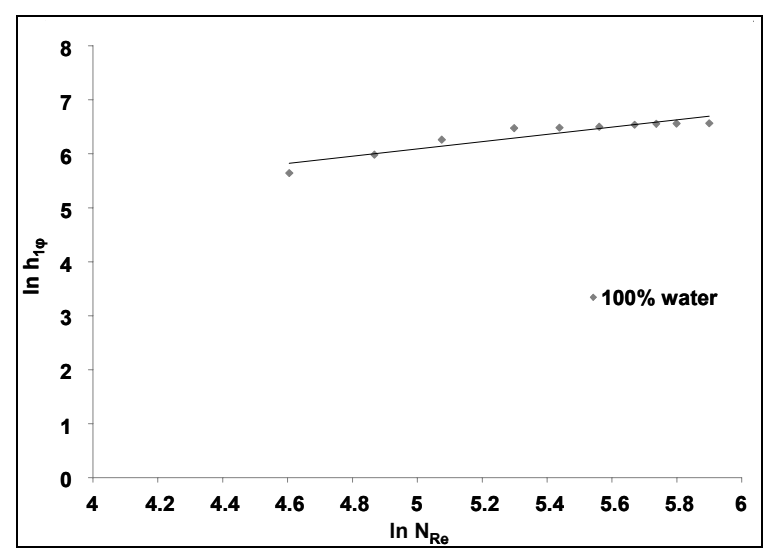

Figure 4: Plot between $\ln \mathrm{N}_{\mathrm{Re}}$ and $\ln \mathrm{h}_{1 \varphi}$ (heat transfer coefficient of pure water).

Table 1: Correlation constants a and $\mathrm{m}$ for the pure diesel and pure water systems.

\begin{tabular}{|c|c|c|}
\hline Mass percentage of diesel & a & m \\
\hline 0 & 15.135 & 0.674 \\
100 & 1.501 & 0.763 \\
\hline
\end{tabular}

Table 2: Inlet and outlet temperatures for different compositions of cold side and hot side fluids

\begin{tabular}{|c|c|c|c|c|c|c|c|c|c|}
\hline \multirow{2}{*}{$\begin{array}{c}\mathrm{N}_{\mathrm{Re}} \text { of tube } \\
\text { side }\end{array}$} & \multicolumn{4}{|c|}{$100 \%$ pure water } & \multirow{2}{*}{$\begin{array}{c}\mathrm{N}_{\mathrm{Re}} \text { of tube } \\
\text { side }\end{array}$} & \multicolumn{4}{|c|}{$20 \%$ diesel-water } \\
\hline & $\mathbf{T}_{\mathrm{c} 1}$ & $\mathbf{T}_{\mathrm{c2}}$ & $T_{\mathrm{h} 1}$ & $T_{\mathrm{h} 2}$ & & $T_{\mathrm{c} 1}$ & $\mathbf{T}_{\mathrm{c} 2}$ & $T_{\mathrm{h} 1}$ & $\mathbf{T}_{\mathrm{h} 2}$ \\
\hline 1106 & 304 & 321.6 & 343 & 331.8 & 1168 & 304 & 316.4 & 343 & 338.8 \\
\hline 1104 & 304 & 314.0 & 343 & 330.2 & 1141 & 304 & 314.0 & 343 & 335.2 \\
\hline 1101 & 304 & 310.8 & 343 & 329.5 & 1132 & 304 & 311.4 & 343 & 334.0 \\
\hline 1099 & 304 & 309.1 & 343 & 329.1 & 1126 & 304 & 310.0 & 343 & 333.2 \\
\hline 1097 & 304 & 308.1 & 343 & 328.8 & 1120 & 304 & 309.0 & 343 & 332.4 \\
\hline 1095 & 304 & 307.3 & 343 & 328.5 & 1118 & 304 & 308.4 & 343 & 332.0 \\
\hline 1094 & 304 & 306.8 & 343 & 328.3 & 1113 & 304 & 308.0 & 343 & 331.4 \\
\hline 1092 & 304 & 306.3 & 343 & 328.2 & 1110 & 304 & 307.6 & 343 & 330.9 \\
\hline 1091 & 304 & 306.0 & 343 & 328.1 & 1106 & 304 & 307.3 & 343 & 330.4 \\
\hline 1090 & 304 & 305.7 & 343 & 327.9 & 1103 & 304 & 307.1 & 343 & 329.9 \\
\hline \multirow{2}{*}{$\begin{array}{c}\mathrm{N}_{\mathrm{Re}} \text { of tube } \\
\text { side }\end{array}$} & \multicolumn{4}{|c|}{$\mathbf{4 0} \%$ diesel- water } & $\mathrm{N}_{\mathrm{Re}}$ of tube & \multicolumn{4}{|c|}{$60 \%$ diesel-water } \\
\hline & $\mathbf{T}_{\mathrm{c} 1}$ & $\mathbf{T}_{\mathrm{c2} 2}$ & $\mathbf{T}_{\mathrm{h} 1}$ & $\mathbf{T}_{\mathrm{h} 2}$ & side & $\mathbf{T}_{\mathrm{c} 1}$ & $\mathbf{T}_{\mathrm{c} 2}$ & $T_{h 1}$ & $\mathbf{T}_{\mathrm{h} 2}$ \\
\hline 1172 & 304 & 316.4 & 343 & 339.4 & 1178 & 304 & 316.0 & 343 & 340.1 \\
\hline 1152 & 304 & 313.2 & 343 & 336.8 & 1162 & 304 & 312.8 & 343 & 338.1 \\
\hline 1142 & 304 & 311.3 & 343 & 335.4 & 1157 & 304 & 310.5 & 343 & 337.4 \\
\hline 1135 & 304 & 310.1 & 343 & 334.4 & 1147 & 304 & 309.9 & 343 & 336.1 \\
\hline 1131 & 304 & 309.0 & 343 & 333.9 & 1143 & 304 & 309.0 & 343 & 335.5 \\
\hline 1128 & 304 & 308.4 & 343 & 333.5 & 1140 & 304 & 308.4 & 343 & 335.1 \\
\hline 1125 & 304 & 308.0 & 343 & 333.0 & 1137 & 304 & 308.0 & 343 & 334.7 \\
\hline 1122 & 304 & 307.6 & 343 & 332.6 & 1134 & 304 & 307.6 & 343 & 334.3 \\
\hline 1119 & 304 & 307.3 & 343 & 332.2 & 1130 & 304 & 307.4 & 343 & 333.8 \\
\hline 1118 & 304 & 307.0 & 343 & 332.1 & 1129 & 304 & 307.1 & 343 & 333.6 \\
\hline \multirow{2}{*}{$\begin{array}{c}\mathbf{N}_{\mathrm{Re}} \text { of tube } \\
\text { side }\end{array}$} & \multicolumn{4}{|c|}{$\mathbf{8 0 \%}$ diesel- water } & $\mathrm{N}_{\mathrm{Re}}$ of tube & \multicolumn{4}{|c|}{$100 \%$ pure diesel } \\
\hline & $T_{\mathrm{c} 1}$ & $\mathbf{T}_{\mathrm{c2}}$ & $T_{h 1}$ & $\mathbf{T}_{\mathrm{h} 2}$ & side & $\mathbf{T}_{\mathrm{c1}}$ & $T_{\mathrm{c} 2}$ & $T_{h 1}$ & $T_{h 2}$ \\
\hline 1183 & 304 & 315.5 & 343 & 340.8 & 1188 & 304 & 315.3 & 343 & 341.4 \\
\hline 1171 & 304 & 312.3 & 343 & 339.3 & 1178 & 304 & 313.0 & 343 & 340.2 \\
\hline 1165 & 304 & 310.6 & 343 & 338.5 & 1177 & 304 & 309.9 & 343 & 340.0 \\
\hline 1159 & 304 & 309.7 & 343 & 337.7 & 1171 & 304 & 309.5 & 343 & 339.2 \\
\hline 1154 & 304 & 309.0 & 343 & 337.0 & 1166 & 304 & 308.9 & 343 & 338.6 \\
\hline 1153 & 304 & 308.3 & 343 & 336.9 & 1163 & 304 & 308.6 & 343 & 338.2 \\
\hline 1151 & 304 & 307.9 & 343 & 336.6 & 1161 & 304 & 308.2 & 343 & 337.9 \\
\hline 1149 & 304 & 307.5 & 343 & 336.4 & 1157 & 304 & 308.0 & 343 & 337.4 \\
\hline 1147 & 304 & 307.2 & 343 & 336.1 & 1154 & 304 & 307.8 & 343 & 337.0 \\
\hline 1145 & 304 & 307.0 & 343 & 335.8 & 1152 & 304 & 307.5 & 343 & 336.7 \\
\hline
\end{tabular}




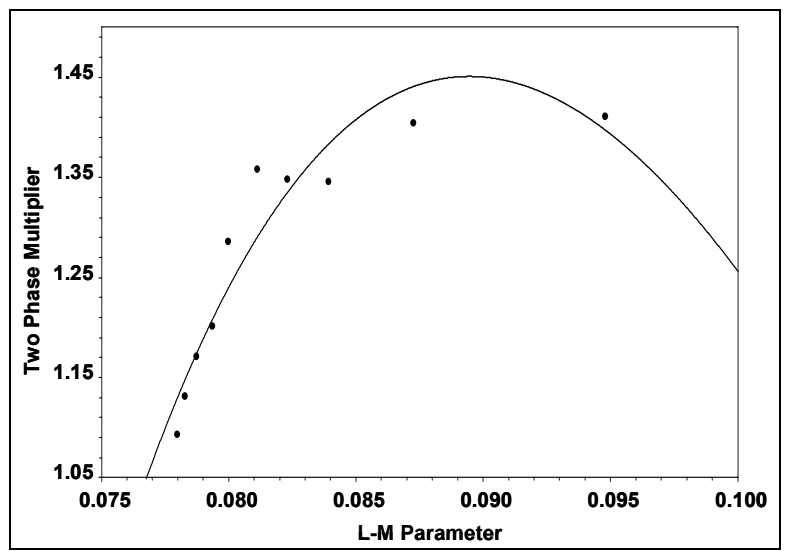

Figure 5: Variation of the Two-Phase Multiplier $\left(\Phi_{\mathrm{L}}\right)$ with the L-M Parameter $\left(\chi_{t t}^{2}\right)$ for the $80 \%$ diesel-water system based on pure diesel

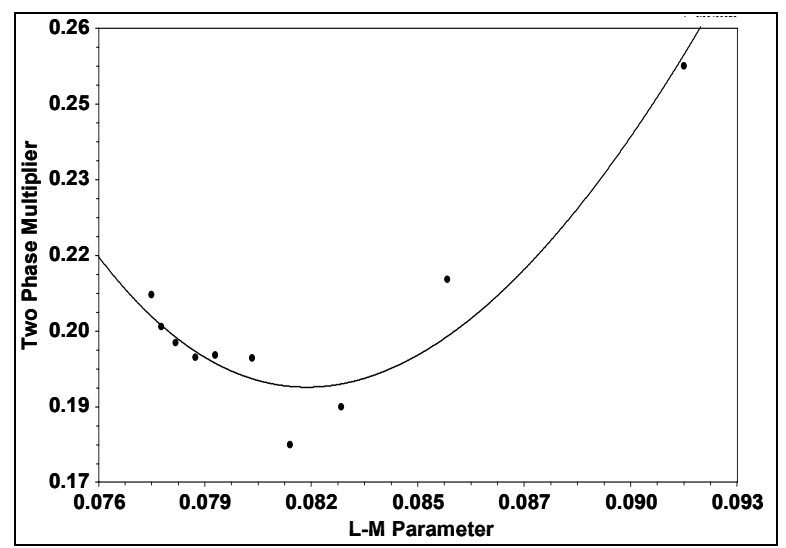

Figure 6: Variation of the Two Phase Multiplier $\left(\Phi_{\mathrm{L}}\right)$ with the L-M Parameter $\left(\chi_{\mathrm{tt}}^{2}\right)$ for the $80 \%$ diesel -water system based on pure water

Table 3: The correlation constants $b, c$ and $d$ in Eq. (19) for varying diesel-water compositions

\begin{tabular}{|c|c|c|c|c|c|c|}
\hline \multirow{2}{*}{ Composition of diesel } & \multicolumn{3}{|c|}{ Pure diesel } & \multicolumn{3}{c|}{ Pure Water } \\
\cline { 2 - 7 } & b & c & d & \multicolumn{1}{c|}{ C } & d \\
\hline $20 \%$ & 30.8 & -14 & -16.9 & -7.22 & 2.5 & 10.3 \\
$40 \%$ & 15.2 & -17 & -1.12 & -7.89 & 8.38 & 1.16 \\
$60 \%$ & 7.06 & -14.5 & -0.105 & -8.6 & 23.1 & 0.191 \\
$80 \%$ & 17.7 & -121 & -0.043 & -4.88 & 41.5 & 0.011 \\
\hline
\end{tabular}

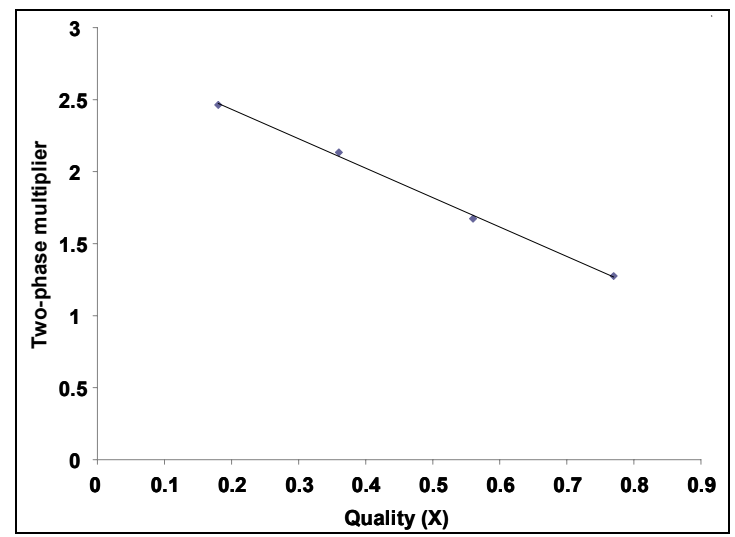

Figure 7: Plot between Quality $(\mathrm{X})$ and Twophase multiplier $\left(\Phi_{\mathrm{L}}\right)$ based on pure diesel for the water-diesel system

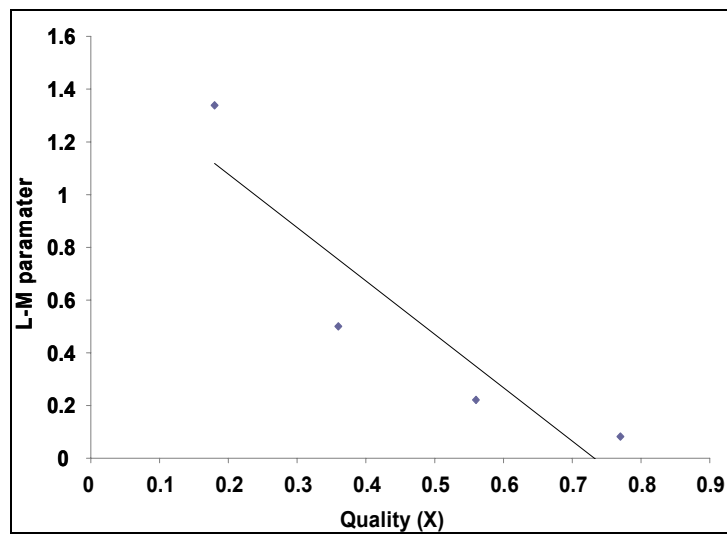

Figure 8: Plot between Quality $(X)$ and the L-M Parameter $\left(\chi_{\mathrm{tt}}^{2}\right)$ based on pure diesel for the waterdiesel system 
Table 4: Comparison of experimental and calculated values of two-phase heat transfer coefficients for $20 \%$ and $40 \%$ diesel-water systems

\begin{tabular}{|c|c|c|c|c|c|c|}
\hline \multirow{2}{*}{$\begin{array}{c}\mathbf{N}_{\mathrm{Re}} \text { of shell } \\
\text { side }\end{array}$} & \multirow[b]{2}{*}{$\mathbf{h}_{2 \varphi \exp }$} & \multicolumn{2}{|c|}{$20 \%$ diesel-water } & \multirow[b]{2}{*}{$\mathbf{h}_{2 \varphi \exp }$} & \multicolumn{2}{|c|}{$40 \%$ diesel-water } \\
\hline & & $\begin{array}{c}\mathbf{h}_{2 \varphi c a l} \text { based on } \\
\text { pure diesel }\end{array}$ & $\begin{array}{l}\mathbf{h}_{2 \varphi c a l} \text { based on } \\
\text { pure water }\end{array}$ & & $\begin{array}{c}\mathbf{h}_{2 \varphi c a l} \text { based on } \\
\text { pure diesel }\end{array}$ & $\begin{array}{c}\mathbf{h}_{2 \varphi c a l} \text { based on } \\
\text { pure water }\end{array}$ \\
\hline 100 & 102.22 & 102.08 & 110.60 & 100.71 & 101.49 & 104.09 \\
\hline 130 & 141.02 & 145.55 & 141.04 & 129.36 & 131.71 & 120.75 \\
\hline 160 & 179.82 & 190.37 & 192.60 & 156.61 & 162.06 & 160.96 \\
\hline 200 & 231.55 & 226.61 & 253.23 & 186.82 & 191.49 & 207.89 \\
\hline 230 & 250.91 & 247.33 & 270.28 & 209.12 & 208.93 & 222.54 \\
\hline 260 & 269.49 & 264.30 & 285.43 & 229.71 & 223.74 & 235.19 \\
\hline 290 & 288.09 & 290.62 & 304.16 & 250.31 & 246.57 & 250.91 \\
\hline 310 & 298.97 & 305.47 & 318.12 & 258.40 & 259.90 & 262.83 \\
\hline 330 & 309.45 & 320.06 & 325.81 & 264.61 & 273.00 & 269.56 \\
\hline 365 & 327.79 & 341.85 & 332.10 & 275.47 & 291.59 & 277.10 \\
\hline
\end{tabular}

Table 5: Comparison of experimental and calculated values of two-phase heat transfer coefficients for $60 \%$ and $80 \%$ diesel-water systems.

\begin{tabular}{|c|c|c|c|c|c|c|}
\hline \multirow[b]{2}{*}{$\begin{array}{c}\mathbf{N}_{\mathrm{Re}} \text { of } \\
\text { shell side }\end{array}$} & \multirow[b]{2}{*}{$\mathbf{h}_{2 \varphi \exp }$} & \multicolumn{2}{|c|}{$60 \%$ diesel-water } & \multirow[b]{2}{*}{$\mathbf{h}_{2 \varphi \exp }$} & \multicolumn{2}{|c|}{$80 \%$ diesel-water } \\
\hline & & $\begin{array}{c}h_{2 \varphi c a l} \text { based on } \\
\text { pure diesel }\end{array}$ & $\begin{array}{c}\mathbf{h}_{\text {2qcal }} \text { based on } \\
\text { pure water }\end{array}$ & & $\begin{array}{c}\mathbf{h}_{2 \varphi c a l} \text { based on pure } \\
\text { diesel }\end{array}$ & $\begin{array}{c}h_{\text {2qcal }} \text { based on } \\
\text { pure water }\end{array}$ \\
\hline 100 & 88.93 & 89.49 & 89.26 & 72.39 & 72.42 & 72.60 \\
\hline 130 & 107.69 & 105.57 & 93.00 & 84.57 & 87.63 & 79.01 \\
\hline 160 & 117.03 & 125.27 & 121.05 & 98.12 & 101.89 & 99.15 \\
\hline 200 & 142.36 & 147.08 & 152.88 & 116.30 & 116.40 & 122.13 \\
\hline 230 & 166.37 & 159.61 & 161.75 & 128.88 & 123.77 & 124.15 \\
\hline 260 & 177.84 & 170.36 & 171.27 & 131.58 & 128.25 & 128.31 \\
\hline 290 & 188.88 & 187.42 & 183.18 & 136.24 & 138.53 & 134.88 \\
\hline 310 & 195.55 & 197.27 & 192.52 & 140.54 & 142.93 & 139.35 \\
\hline 330 & 202.17 & 207.46 & 196.39 & 143.65 & 147.59 & 141.54 \\
\hline 365 & 214.48 & 221.45 & 202.50 & 149.10 & 156.08 & 143.54 \\
\hline
\end{tabular}

Table 6: Average absolute deviation of $h_{2 \varphi}$ based on pure water and pure diesel

\begin{tabular}{|c|c|c|}
\hline \multirow{2}{*}{ Composition of diesel } & \multicolumn{2}{|c|}{ Average absolute deviation based on } \\
\cline { 2 - 3 } & Pure diesel & Pure water \\
\hline $20 \%$ & 2.549 & 5.692 \\
$40 \%$ & 2.237 & 3.730 \\
$60 \%$ & 2.877 & 4.434 \\
$80 \%$ & 2.470 & 2.633 \\
\hline
\end{tabular}

\section{CONCLUSION}

Two-phase flow through a 1-2 pass shell and tube exchanger using a water-diesel system was studied. The correlations between $\mathrm{X}, \Phi_{\mathrm{L}}$ and $\chi_{\mathrm{tt}}{ }^{2}$ will be useful for predicting two-phase heat transfer coefficients using pure phase thermo-physical properties. The correlation developed for the diesel-water system is useful for identifying heat transfer coefficients of twophase systems for the range of Reynolds number studied. Based on the summary in Table 6 , it can be concluded that, for this system, diesel is a better reference fluid compared to water since the average absolute deviation varies from 2.24 to 2.88 percent compared to water (2.63 to 5.69 percent). Further studies on Palm oil-Water, Nitrobenzene-Water, Oleic acid-Water and Castor oil-Water are being carried out to verify whether Palm oil, Nitrobenzene, Oleic acid and Castor oil are also better reference fluids compared to water. The specific reason for diesel being a better reference fluid should be clarified by this comprehensive study of similar systems.

\section{NOMENCLATURE}

$\mathrm{a}, \mathrm{m} \quad$ constants for pure water and pure diesel in Equation (5)

$\mathrm{A}_{\mathrm{h}} \quad$ heat transfer area

$\mathrm{A}_{\mathrm{s}} \quad$ cross flow area $\mathrm{m}^{2}$

$\mathrm{m}^{2}$ 
b, c, d constants of the heat capacity correlation Equation (19)

$\mathrm{B}_{\mathrm{s}} \quad$ baffle spacing

$\mathrm{Cp}_{\mathrm{h}} \quad$ specific heat of hot water

$\mathrm{D}_{\mathrm{i}} \quad$ inner diameter of the tube

$\mathrm{D}_{\mathrm{o}} \quad$ outer diameter of the tube

$\mathrm{D}_{\mathrm{s}} \quad$ inner diameter of the shell

$\mathrm{D}_{\mathrm{e}} \quad$ equivalent diameter

$\mathrm{F}_{\mathrm{t}} \quad$ temperature correction

factor

$\mathrm{G}_{\mathrm{s}} \quad$ mass velocity

$\mathrm{h}_{1 \varphi} \quad$ heat transfer coefficient of pure diesel/pure water

$\mathrm{h}_{2 \varphi} \quad$ two-phase heat transfer coefficient

$\mathrm{h}_{1 \mathrm{t} \varphi} \quad$ tube side (hot water) heat transfer coefficient

$\mathrm{k}$ thermal conductivity of hot water

$\mathrm{k}_{\mathrm{w}} \quad$ thermal conductivity of the tube wall material

L length of tube

$\mathrm{m}_{\mathrm{h}} \quad$ flow rate of hot water

$\mathrm{N}_{\mathrm{Nu}} \quad$ Nusselt number

$\mathrm{N}_{\text {Pr }} \quad$ Prandtl number

$\mathrm{N}_{\mathrm{Re}} \quad$ Reynolds number

$\mathrm{Pt}$ tube pitch (m)

$\mathrm{R}, \mathrm{S}$ dimensionless temperature ratios

$\mathrm{T}_{\mathrm{h} 1} \quad$ inlet temperature of hot water on the tube side

$\mathrm{T}_{\mathrm{h} 2} \quad$ outlet temperature of hot water on the tube side

$\mathrm{T}_{\mathrm{c} 1} \quad$ inlet temperature of cold fluid on the shell side

$\mathrm{T}_{\mathrm{c} 2} \quad$ outlet temperature of cold

fluid on the shell side

$\mathrm{v}_{\mathrm{f}} \quad$ volumetric flow rate of diesel

$\mathrm{V}_{\mathrm{m}} \quad$ flow rate of a diesel-water mixture

$\mathrm{v}_{\mathrm{w}} \quad$ volumetric flow rate of water

$\mathrm{X}$ quality parameter for the two-phase system

\section{Greek Letters}

$\begin{array}{ll}\chi_{\mathrm{tt}}^{2} & \begin{array}{l}\text { Lockhart-Martinelli (L-M) } \\ \text { parameter }\end{array} \\ \Phi_{\mathrm{L}} & \begin{array}{l}\text { two phase multiplier } \\ \Delta \mathrm{T}_{\mathrm{lm}}\end{array} \\ & \begin{array}{l}\text { logarithmic mean } \\ \text { temperature }\end{array} \\ \Delta \mathrm{T}_{\mathrm{m}} & \text { true temperature difference }\end{array}$

V. Alagesan and S. Sundaram

\begin{tabular}{|c|c|c|c|}
\hline & $v$ & velocity of hot water & $\mathrm{m} / \mathrm{s}$ \\
\hline & $\mu$ & viscosity of hot water & $\mathrm{kg} / \mathrm{m} \mathrm{s}$ \\
\hline $\mathrm{m}$ & $\mu_{\mathrm{w}}$ & viscosity of water & $\mathrm{kg} / \mathrm{m} \mathrm{s}$ \\
\hline $\mathrm{J} / \mathrm{kg} \mathrm{K}$ & $\mu_{\mathrm{f}}$ & viscosity of diesel & $\mathrm{kg} / \mathrm{m} \mathrm{s}$ \\
\hline $\mathrm{m}$ & $\mu_{\mathrm{m}}$ & viscosity of diesel-water & $\mathrm{kg} / \mathrm{m} \mathrm{s}$ \\
\hline $\mathrm{m}$ & & mixture & \\
\hline $\mathrm{m}$ & $\rho$ & density of hot water & \\
\hline & $\rho_{\mathrm{w}}$ & density of water & $\mathrm{kg} / \mathrm{m}^{3}$ \\
\hline & $\rho_{\mathrm{f}}$ & density of diesel & $\mathrm{kg} / \mathrm{m}^{3}$ \\
\hline $\mathrm{kg} / \mathrm{m}^{2} \mathrm{~s}$ & $\rho_{\mathrm{m}}$ & $\begin{array}{l}\text { density of diesel-water } \\
\text { mixture }\end{array}$ & $\mathrm{kg} / \mathrm{m}^{3}$ \\
\hline
\end{tabular}

$\mathrm{W} / \mathrm{m}^{2} \mathrm{~K}$

$\mathrm{W} / \mathrm{m}^{2} \mathrm{~K}$

REFERENCES

W/m² K Awwad, A., Xin, R. C., Dong, Z. F., Ebadiam, M. A. and Soliman, H. M., Measurement and $\mathrm{W} / \mathrm{m} \mathrm{K} \quad$ correlation of the pressure drop in air-water twophase flow in horizontal helicoidal pipes. Int. J.

W/m K Multiphase Flow, 21, 607-619 (2000).

Dowlati, R., Chan, A. M. C and Kawaji, M., Hydrodynamics of two-phase flow across horizontal in-line and staggered rod bundles. J. Fluid Eng., 114, 450-456 (1992).

Benbelk, A. Shannak, Frictional pressure drops of gas-liquid two-phase flow in pipes. Nuclear Eng. Design, 238, 3277-3284 (2008).

Lockhart, R. W. and Martinelli, R. C., Proposed correlation of data for isothermal two-phase two

K

K

$\mathrm{K}$

$\mathrm{K}$

$\mathrm{m}^{3} / \mathrm{s}$

$\mathrm{m}^{3} / \mathrm{s}$

$\mathrm{m}^{3} / \mathrm{s}$ component flow in pipes. Chem. Eng. Prog., 43, 39-48 (1949).

Ramachandran, S., Kalaichelvi, P., Sundaram, S., Experimental heat transfer correlations for a liquid-liquid two-phase system in a compact heat exchanger. Indian J. Chem Tech., 1, 14-19 (2006).

Ramachandran, S., Kalaichelvi, P., Sundaram, S., Heat transfer studies in a spiral plate heat exchanger for water-palm oil two-phase system. Braz. J. Chem Eng., 25, 483-490 (2008).

Rani Hemamalini, R., Partheeban, P., Sarat Chandra Babu, C., Sundaram, S., The effect on pressure drop across horizontal pipe and control valve for air/palm oil two-phase flow. Int. J. Heat Mass Trans., 48, 2911-2921 (2005).

Sinnott, R. K., Chemical Engineering Design Volume 6. Butterworth-Heinemann Publishers, Third Edition (2000).

Spedding, P. L., Regime maps for air-water twophase flow for both vertically downward and upward flow. Chem. Eng. Science, 46, 1773-1790 (1980).

Thorbjorn and Johannessen, A theoretical solution $\mathrm{K}$ of the Lockhart and Martinelli flow model for 
calculating two-phase flow pressure drop and hold up. Int. J. Heat Mass Trans., 15, 1443-1449 (1972).

Vijayarangan, B. R., Jayanti, S., Balakrishnan, A. R., Pressure drop studies on two-phase flow in uniformly heated vertical tube at pressure up to the critical point. Int. J. Heat Mass Trans., 50, 1879-1891 (2007).
Vlasogiannis, P., Karagiannis, G., Argyropoulo, P., Bontozoglou, V., Air-water two-phase flow and heat transfer in a plate type exchanger. Int. J. Multiphase Flow, 28, 757-772 (2002).

Xiuzhong Shen, Kaichiro Mishima, Hideo Nakamura, Two-phase distribution in a vertical large diameter pipe. Int. J. Heat Mass Trans., 48, 211-225 (2005). 